\title{
Performance of young growing pigs (17-34 kg) fed rye-based diets selected for reduced viscosity
}

\author{
P.A. Thacker', G.L. Campbell' ${ }^{1}$ and G.J. Scoles ${ }^{2}$ \\ 'Department of Animal Science, \\ University of Saskatchewan \\ Saskatoon, Saskatchewan S7N 5B5, Canada \\ ${ }^{2}$ Department of Plant Science, \\ University of Saskatchewan \\ Saskatoon, Saskatchewan S7N SA8, Canada
}

(Received 25 August 1999; accepted 7 October 1999)

\begin{abstract}
Forty eight crossbred pigs $(17.0 \mathrm{~kg}$ ) were assigned to one of three dietary treatments in a $3 \times 2$ factorial design experiment. The control diet was based on bartey and soyabean meal while the two experimental diets contained $60 \%$ of either high or low viscosity rye. Pigs fed either of the rye-based diets had significantly higher $(\mathrm{P}<0.05)$ digestibility coefficients for dry matter and gross energy than did pigs fed barley. The digestibility coefficients for dry matter, crude protein and gross energy were numerically higher for pigs fed the low viscosity rye than the high viscosity rye $(\boldsymbol{P}>0.05)$. Pigs fed either of the rye-based diets consumed significantly less feed and gained weight at a slower rate than did pigs fed the barley-based diet. The pigs fed the low viscosity rye gained $8.7 \%$ faster and consumed $9 \%$ more feed than pigs fed the high viscosity diet but these differences did not reach statistical significance $(\mathrm{P}>0.05)$. The overall results indicate that selection to reduce the viscosity of rye only slightly improved the nutritive value of rye for pigs. The magnitude of the improvement indicates that a substantial reduction in viscosity is necessary in order to observe a measurable difference in pig performance.
\end{abstract}

KEY WORDS: rye, viscosity, pigs, digestibility, growth

\section{INTRODUCTION}

Ryc (Secale cereale) is not widely utilised as an energy source for swine. The classical explanation for this relates to its high ergot content (Friend and MacIntyre, 1970) resulting in relatively poor performance when pigs are fed rye-based 
diets (Bowland, 1966; Friend and MacIntyre, 1969, 1970). While ergot is undoubtably toxic, research with poultry fed rye-based diets has shown that rye also contains high levels of soluble pentosans which also reduce broiler performance. Pentosans partially solubilize during digestion, resulting in a highly viscous intestinal fluid that interferes with digestion (Campbell et al., 1983; Fengler et al., 1988). The negative effects can be overcome, to a limited extent, by supplementation of the diet with xylanase (Pettersson and Aman, 1988; GrootWassink et al., 1989; Teitge et al., 1990).

Enzyme supplementation has also been shown to improve the performance of pigs fed rye based diets (Thacker et al., 1991; Thacker and Baas, 1996) indicating that pentosans may also be a problem for swine. The degree of improvement is not as great as that seen with poultry and tends to be greater when diets were fed in a mash form rather than as a pellet (Thacker et al., 1991)

Recently a breeding program has been undertaken at the University of Saskatchewan to reduce the viscosity of rye varieties which may extend the use of rye as a feed grain with or without enzyme supplementation. The objective of the following study was to compare the performance of pigs fed diets based on rye previously selected for high and low viscosity. Young growing pigs were chosen as the experimental model due to the greater sensitivity of an immature digestive system to soluble fibre.

\section{MATERIAL AND METHODS}

\section{Plant breeding program}

In 1993, 224 single plants of the spring rye cultivar Gazelle (Sosulski and Curran, 1975) were harvested and analyzed for viscosity using a Brookfield viscometer. Single seeds from each of the 25 plants with the highest viscosity and the 25 plants with lowest viscosity were grown in separate isolation areas in a green house and the plants were allowed to open-pollinate with each other. Twelve seeds from each plant were taken and bulked to form a low viscosity and high viscosity bulk. These bulks were seeded in 1994 as spaced plants in isolation from each other as well as from other rye. Single plants were harvested, viscosity analyzed and seed from some of the highest and lowest viscosity plants was planted in the greenhouse to provide a population of about 200 plants. A similar process of recurrent selection was repeated in 1995 and 1996. In 1997, remnant seed of the high and low viscosity selections grown in 1996 was thinly planted in isolated plots. Two hundred single plants were harvested for further selection. The remainder of the plot was harvested as a bulk. These two lots of seed were used to plant two half- 
acre plots in isolation from each other and from other rye in 1998. The seed from these increases was then used in the following feeding trial.

\section{Feeding trial}

Forty cight crossbred pigs (Camborough, Pig Improvement Canada Ltd, Acme Alberta) weighing an average of $17.0 \pm 1.44 \mathrm{~kg}$ were assigned on the basis of sex, weight and litter to one of three dietary treatments in a $3 \times 2$ factorial ( 3 cereal grains $\times 2$ sexes) design experiment. The control diet was based on barley and soyabean meal while the two experimental diets contained $60 \%$ of either high or low viscosity rye. Eight castrates and eight gilts were fed each diet.

The experimental diets were formulated to supply $19 \%$ crude protein (Table 1 )

TABLE 1

Formulation and chemical composition of diets containing either barley or high or low viscosity rye

\begin{tabular}{lccc}
\hline & Barley & $\begin{array}{c}\text { High viscosity } \\
\text { rye }\end{array}$ & $\begin{array}{c}\text { Low viscosity } \\
\text { rye }\end{array}$ \\
\hline Diet formulation, \% as fed & & & \\
Barlcy $(9.93 \%$ CP) & 67.90 & 14.89 & 15.45 \\
High viscosity rye (13.60\% CP) & - & 60.00 & - \\
Low viscosity rye (15.72\% CP) & - & - & 60.00 \\
Soyabcan meal (45.45\% CP) & 25.86 & 19.44 & 18.80 \\
Tallow & 2.90 & 1.98 & 2.05 \\
Dicalcium phosphate & 1.45 & 1.57 & 1.58 \\
Limestone & 0.89 & 0.86 & 0.86 \\
Salt & 0.50 & 0.50 & 0.50 \\
Vitanin-mineral premix & 0.50 & 0.50 & 0.50 \\
Lysine HCl & - & 0.12 & 0.12 \\
Methionine & - & 0.04 & 0.04 \\
Threonine & - & 0.10 & 0.10 \\
& & & \\
Chemical composition, \% as ted & 11.39 & 11.52 & 11.16 \\
Moisture & 18.80 & 19.09 & 18.81 \\
Crude protein & 5.49 & 5.05 & 5.10 \\
Ash & 4.86 & 3.56 & 3.85 \\
Ether extract & 6.47 & 4.10 & 4.60 \\
Acid detcrgent fibre & 4060 & 3968 & 4018 \\
Gross energy, kcal/kg & 3105 & 3139 & 3249 \\
Digestible energy, kcal/kg & 5.43 & 18.70 & \\
Diet viscosity, cP & & & \\
\hline
\end{tabular}

' supplied per kilogram of diet: 8250 IU vitamin A; 825 IU vitamin D3; 40 IU vitamin E; 4 mg vitamin $\mathrm{K}$; $1 \mathrm{mg}$ thiamin; $5 \mathrm{mg}$ riboflavin; $35 \mathrm{mg}$ niacin; $15 \mathrm{mg}$ pantothenic acid; $2 \mathrm{mg}$ folic acid; $12.5 \mathrm{mg}$ vitamin $\mathrm{B}_{12} ; 0.2 \mathrm{mg}$ biotin; $80 \mathrm{mg}$ iron: $25 \mathrm{mg}$ manganese; $100 \mathrm{mg}$ zinc; $50 \mathrm{mg} \mathrm{Cu} ; 0.5 \mathrm{mg}$ I; $0.1 \mathrm{mg}$ selenium 
with the rye based diets supplemented with synthetic lysine, methionine and threonine to provide a similar balance of amino acids as the barley-based diet. All diets were supplemented with sufficient vitamins and minerals to meet or exceed the levels recommended by the National Research Council (1998). The diets were fed in meal form. The trial was run for 28 days and concluded when the pigs reached an average weight of $33.7 \mathrm{~kg}$.

The pigs were housed in groups of four in $2.7 \times 3.6 \mathrm{~m}$ concrete floored pens and were provided water ad libitum. The pens were equipped with four individual feeders. Each pig was allowed access to its own individual feeder for 30-min twice daily (07:00 and 15:00 h).

Individual body weights, feed consumptions and feed efficiencies were recorded weekly. Pigs were assigned to feeders in such a way as to minimize the potential for treatment effects to be confounded with environmental effects.

\section{Digestibility trial}

Total tract digestibility coefficients for dry matter, crude protein and gross energy were determined using three castrates and three gilts per treatment starting at an average weight of $28 \mathrm{~kg}$. The pigs were housed under identical conditions as those used in the growth trial and were fed the same diets as those used during the growing stage modified only by the addition of $5 \mathrm{~g} \mathrm{~kg}^{-1}$ chromic oxide as a digestibility marker. The marked feed was provided for a seven day acclimatization period, followed by a three day faecal collection. Faecal collections were made by bringing animals into a clean room immediately after feeding and recovering freshly voided faeces. The faecal samples were frozen for storage. Prior to analysis, the samples were dried in a forced air oven dryer at $66^{\circ} \mathrm{C}$ for $60 \mathrm{~h}$, followed by fine grinding (0.5-mm screen).

\section{Chemical analysis}

Analysis of samples for dry matter, crude protein, acid detergent fibre, ash and ether extract were conducted according to the methods of the Association of Official Analytical Chemists (1990). An adiabatic oxygen bomb calorimeter was used to determine gross energy content. Chromic oxide was determined by the method of Fenton and Fenton (1979).

Diet viscosity was determined following the method of Scoles et al. (1993). A $0.3 \mathrm{~g}$ sample of diet was mixed with $900 \mathrm{uL}$ of $0.1 \mathrm{M}$ sodium acetate buffer $(\mathrm{pH} 5.0)$ and incubated $30 \mathrm{~min}$ at $40^{\circ} \mathrm{C}$. The slurries were centrifuged $(5.0 \mathrm{~min}$ at $12,000 \times \mathrm{g}$ ), the supernatant decanted and viscosity (centipose) read using a Brookfield cone-plate viscometer (Model LVTDCP-11, Brookfield Engineering Laboratories Inc., Stoughton, MA) maintained at $25^{\circ} \mathrm{C}\left(12 \mathrm{rpm}\right.$; Sheer rate $\left.90 \mathrm{~s}^{-1}\right)$. 


\section{Statistical analysis}

Both the pig performance and the digestibility data were analyzed as a $3 \times 2$ factorial using the General Linear Models procedure of the Statistical Analysis System Institute, Inc. (SAS 1985) with the factors in the model consisting of treatment, sex and their interaction. Means were compared using Duncan's New Multiple-Range Test (Steel and Torrie, 1980). Individual feeding of animals and the distribution of treatments across pens allowed pig to be used as the replicate rather than pen.

\section{RESULTS}

The results of the chemical analysis conducted on the feeds is presented in Table 1. The barley-based diet had a slightly lower ash and ether extract content than the rye-based diets while the acid detergent fibre content of the rye-based diet was lower than that of the barley based diet. The high viscosity rye diet had a viscosity of $18.7 \mathrm{cP}$ compared with $4.24 \mathrm{cP}$ for the low viscosity rye. This value was lower than the $5.43 \mathrm{cP}$ viscosity determined for the barley based diet.

Digestibility coefficients for dry matter, crude protein and gross energy are presented in Table 2. Pigs fed either of the rye-based diets had significantly higher $(\mathrm{P}=0.001)$ digestibility coefficients for dry matter and gross energy than did pigs fed barley. The digestibility coefficients for crude protein was significantly higher for pigs fed the high viscosity rye-based diet than for pigs fed the high viscosity rye or the barley based diet $(\mathrm{P}=0.001)$. There were no differences in digestibility coefficients when measured in gilts or castrates.

Pigs fed either of the rye-based diets consumed significantly less feed and gained weight at a slower rate than did pigs fed the barley-based diet (Table 2). The pigs fed the low viscosity rye gained $8.7 \%$ faster and consumed $9 \%$ more feed than pigs fed the high viscosity rye diet but these differences did not reach statistical significance $(\mathrm{P}>0.05)$. Castrates had a significantly higher $(\mathrm{P}<0.05)$ feed conversion than gilts while gain and feed intake did not differ due to the sex of the pig.

\section{DISCUSSION}

Pigs fed the rye-based diets had higher digestiblity coefficients for dry matter and gross energy relecting the lower fibre content of rye than barley. As such, these results agree with our previous findings (Thacker et al., 1991, 1992) and those of others (Friend and MacIntyre, 1969; Savage et al., 1978). The increased nutrient digestibility did not directly correlate with improved growth rate, as pigs 
Digestibility coefficients for pigs fed diets based on either barley or high or low viscosity rye

TABLE 2

\begin{tabular}{|c|c|c|c|c|c|c|c|c|c|c|}
\hline \multirow{2}{*}{$\begin{array}{l}\text { Digestibility } \\
\text { coefficients, \% }\end{array}$} & \multirow[t]{2}{*}{ Barley } & \multirow{2}{*}{$\begin{array}{c}\text { High } \\
\text { viscosity } \\
\text { rye }\end{array}$} & \multirow{2}{*}{$\begin{array}{l}\text { Low } \\
\text { viscosity } \\
\text { rye }\end{array}$} & \multirow[t]{2}{*}{ SEM $^{\prime}$} & \multirow[t]{2}{*}{ Castrate } & \multirow[t]{2}{*}{ Gilts } & \multirow[t]{2}{*}{ SEM } & \multicolumn{3}{|c|}{ Probability } \\
\hline & & & & & & & & Treat & Sex & $\mathrm{SxT}$ \\
\hline Dry matter & $77.40^{\mathrm{a}}$ & $81.16^{b}$ & $82.16^{b}$ & 0.50 & 80.48 & 80.00 & 0.42 & 0.001 & 0.437 & 0.696 \\
\hline Crude protein & $77.80^{\circ}$ & $77.26^{\mathrm{a}}$ & $80.54^{b}$ & 0.89 & 78.61 & 78.46 & 0.72 & 0.049 & 0.886 & 0.651 \\
\hline Gross energy & $76.49^{\mathrm{a}}$ & $79.12^{\mathrm{h}}$ & $80.86^{b}$ & 0.65 & 79.16 & 78.49 & 0.53 & 0.002 & 0.394 & 0.673 \\
\hline
\end{tabular}

${ }^{1}$ Standard Error of the Mean

within main effect, means followed by different letters are significantly different at the P values indicated

I

$\underset{1}{2}$

Performance of growing pigs (17-33 kg) fed diets based on either barley or high or low viscosity rye

\begin{tabular}{|c|c|c|c|c|c|c|c|c|c|c|}
\hline \multirow[t]{2}{*}{ Indices } & \multirow[t]{2}{*}{ Barley } & \multirow{2}{*}{$\begin{array}{l}\text { High } \\
\text { viscosity } \\
\text { rye }\end{array}$} & \multirow{2}{*}{$\begin{array}{c}\text { Low } \\
\text { viscosity } \\
\text { rye }\end{array}$} & \multirow[t]{2}{*}{ SEM $^{\prime}$} & \multirow[t]{2}{*}{ Castrate } & \multirow[t]{2}{*}{ Gilts } & \multirow[t]{2}{*}{ SEM } & \multicolumn{3}{|c|}{ Probability } \\
\hline & & & & & & & & Treat & Sex & SxT \\
\hline Daily gain, $\mathrm{kg}$ & $0.69^{\mathrm{a}}$ & $0.52^{b}$ & $0.57^{\mathrm{b}}$ & 0.02 & 0.61 & 0.57 & 0.01 & 0.001 & 0.156 & 0.240 \\
\hline Daily feed intake, $\mathrm{kg}$ & $1.27^{2}$ & $1.00^{b}$ & $1.10^{\mathrm{b}}$ & 0.03 & 1.13 & 1.11 & 0.02 & 0.001 & 0.695 & 0.323 \\
\hline Feed conversion & 1.84 & 1.94 & 1.94 & 0.04 & $1.86^{\mathrm{a}}$ & $1.96^{\mathrm{b}}$ & 0.02 & 0.122 & 0.034 & 0.613 \\
\hline
\end{tabular}

' Standard Error of the Mean

within main effect, means followed by different letters are significantly different at the $\mathrm{P}$ values indicated 
fed either of the rye-based diets gained weight significantly slower than did the pigs fed the barley-based diet. These findings agree with our previous work with older pigs (Thacker et al., 1991, 1992).

The reduced growth rate for the pigs fed rye would appear to be due to the $13-20 \%$ reduction in feed intake compared with pigs fed the barley-based diet. This is substantially greater than previously observed with older pigs and most likely reflects the greater sensitivity of the younger animal. The higher consumption $(\mathrm{P}>0.05)$ for pigs fed the low viscosity as compared with the high viscosity rye is supportive of viscosity being a determining factor in feed consumption. The genetic selection to reduce viscosity of the rye grain resulted in a 4-fold reduction in viscosity for the low viscosity rye-based diet. The reduction in viscosity produced a significant improvement in protein digestibility compared with the high viscosity rye. Unfortunately, growth rate and feed conversion were only slightly increased for pigs fed the low viscosity rye compared with the high and these differences did not reach statistical significance.

In conclusion, breeding efforts towards reducing the viscosity of rye were only modestly successful in improving the nutritive value of rye for pigs. Clearly, the viscosity of rye must be substantially below barley and probably equivalent to wheat, in order to completely eliminate the viscosity effect on pig performance. However, it may be anticipated that continued viscosity reduction may reduce restrictions relating to level of inclusion, feed treatment (mash vs pellets; Bazylo, 1990), enzyme inclusion and/or age and species of animal to which rye is fed.

\section{REFERENCES}

AOAC, 1990. Official Methods of Analysis. 15th Edition. Association of Official Analytical Chemists, Washington, DC

Bazlo R.B., 1990. Rye In: P.A. Thacker, R.N. Kirkwood (Editors). Nontraditional Feed Sources for Use in Swine Production. Butlerworth Publishers, Stoncham, MA, pp. 363-372

Bowland J.P., 1966. Rye for market pigs. University of Alberta. 45th Annual Feeders Day Report $51,1-3$

Campbell G.L, Campbell L.D., Classen H.L., 1983. Utiliztion of rye by chickens: Effect of microbial status, diet gamma irradiation and sodium taurocholate supplementation. Brit. Poultry Sci. 24, 191-203

Fengler A.I., Pawlik J.R., Marquardt R.R., 1988, lmprovement in nutrient retention and changes in chicks fed rye-containing diets supplemented with fungal enzymes, sodium taurdcholate and penicillin. Can. J. Anim. Sci. 68, 483-491

Fenton T.W., Fenton M., 1979. An improved procedure for the determination of chromic oxide in feed and faeces. Can. J. Anim. Sci. 59, 631-634

Friend D.W., MacIntryc T.M., 1969. Digestibility of ryc and its value in pelleted rations for pigs. Can. J. Anim. Sci. 49, 375-381

Friend D.W., MacIntrye T.M., 1970. Effect of rye ergot on growth and nitrogen retention in growing pigs. Can. J. Comp. Med. 34, 198-202 
GrootWassink J.W., Campbell C.L., Classen H.L., 1989. Fractionation of a crude pentonsanase (arahinoxylanase) for improvement of the nutritional value of rye for broiler chickens. J. Sci. Food Agr. 46, 289-300

National Research Council, National Academy of Sciences, 1998. Nutrient Requirements of Domestic Animals. No. 2. Nutrient Requirements of Swine. 10th Edition. NAS-NRC, Washington, DC

Pettersson D., Aman P., 1988. Effects of enzyme supplementation of diets based on wheat, rye or triticale on their productive value for broiler chickens. Anim. Feed Sci. Tech. 20, 313-324

Savage G., Smith W.C., Pickles J., 1978. The use of rye in the diet of the growing pig. Anim. Prod. 26, 398 (Abstr.)

Scoles G.J., Campbell G.L., McLeod J.G., 1993. Variability for grain extract viscosity in inbred lines of an $\mathrm{F}_{2}$ population of rye (Secale cereale L.). Can. J. Plant Sci. 73, 1-6

Sosulski F.W., Curran W.A., 1975. Gazelle spring ryc. Can. J. Plant Sci. 55, 629

Statistical Analysis System Institute, Inc., 1985. SAS Uscrs Guide, Version S. SAS Institute Inc., Cary, NC

Steel R.G.D., Torrie J.H., 1980. Principles and Procedures of Statictics. A Biometrical Approach. McGraw-Hill Book Company, New York

Teitge D.A., Campbell G.L., Classen H.L., Thacker P.A., 1990. Heat pretreatment as a means of improving the response to dietary pentosanase in chicks fed rye. Can. J. Anim. Sci, 71, 507-514

Thacker P.A., Baas T.C., 1996. Effects of gastric pH on the activity of exogenous pentosanase and the effect of pentosanase supplementation of the diet on the performance of growing finishing pigs. Anim. Feed Sci. Tech. 63, 187-200

Thacker P.A., Campbell G.L., GrootWassink J.W.D., 1991. The effect of enzyme supplementation on the nutritive value of rye-based diets for swine. Can. J. Anim. Sci. 71, 489-496

Thacker P.A., Campbell G.L., GrootWassink J.W.D., 1992. The effect of salinomycin and enzyme supplementation on the performance of pigs fed barley or ryc-based diets. Can. J. Anim. Sci. $72,117-125$

\section{STRESZCZENIE}

\section{Przyrosty i strawność skladników pokarmowych u prosiąt żywionych dawkami zawierającymi żyto selekcjonowane w kierunku obniżonej lepkości}

Doświadczenie, w układzie czynnikowym $3 \times 2$, przeprowadzono na 48 prosiętach mieszańcach $(17,0 \mathrm{~kg})$, podzielonych na 3 grupy. Podstawowymi paszami w dawce kontrolnej był jęczmień $\mathrm{i}$ śruta sojowa, w dwóch doświadczalnych $60 \%$ stanowiło żyto o wysokiej lub niskiej lepkości. Współczynniki strawności suchej masy i energii brutto obydwóch dawek z żytem były istotnie większe $(\mathrm{P}<0,05)$ niż dawki kontrolnej. Białko dawki z żytem o niskiej lepkości było lepicj trawione $(\mathrm{P}<0,05)$ niż dawki z żytem o wysokiej lepkości. Prosięta żywione obydwiema dawkami z żytem zjadały istotnic mniej paszy a przyrosty ich były mniejsze niż zwierząt otrzymujących dawkę kontrolną. Prosięta otrzymującc żyto o niskiej lepkości przyrastały lepiej o $8,7 \%$ i zjadały o $9 \%$ więcej paszy niż zwierzçta żywione żytem o wysokiej lepkości, lecz różnice te nie były statystycznie istotne $(\mathrm{P}>0,05)$.

Otrzymane wyniki wskazują, że selekcja żyta w kierunku obniżenia lcpkości tylko nieznacznie poprawia wartość pokarmową tego ziarna dla świń, co wskazuje na konieczność istotnego obniżenia lepkości ziarna dla uzyskania znaczących różnic w produkcyjność świń. 